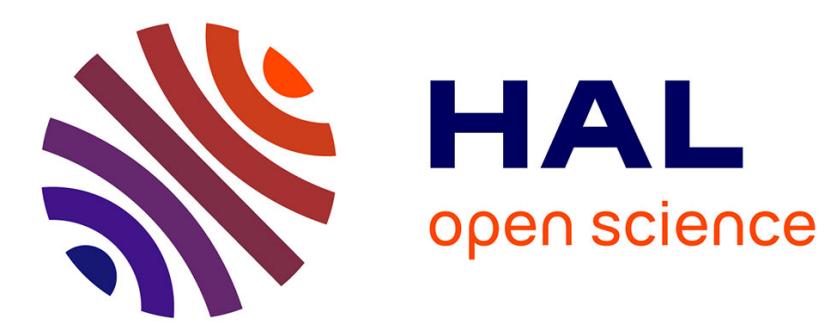

\title{
Xenakis' Thought through his Writings
}

Makis Solomos

\section{- To cite this version:}

Makis Solomos. Xenakis' Thought through his Writings. Journal of New Music Research, 2004, 33

(2), pp.125 - 136. 10.1080/0929821042000310603 . hal-01789818

\section{HAL Id: hal-01789818 \\ https://hal.science/hal-01789818}

Submitted on 1 Jun 2018

HAL is a multi-disciplinary open access archive for the deposit and dissemination of scientific research documents, whether they are published or not. The documents may come from teaching and research institutions in France or abroad, or from public or private research centers.
L'archive ouverte pluridisciplinaire HAL, est destinée au dépôt et à la diffusion de documents scientifiques de niveau recherche, publiés ou non, émanant des établissements d'enseignement et de recherche français ou étrangers, des laboratoires publics ou privés. 


\title{
Xenakis' Thought through his Writings
}

\author{
Makis Solomos \\ Université Montpellier 3 \\ Institut Universitaire de France, Paris \\ Makis.Solomos@univ-montp3.fr \\ Journal of New Music Research vol. 33 n², 2004, p. 125-136. DOI : \\ $10.1080 / 0929821042000310603$
}

\begin{abstract}
This paper moves from the observation that we can hardly characterize Xenakis' writings by using too restricted definitions and categories. In order to address the several lines of thought expressed in his writings, this paper attempts to somehow preserve their essential fluidity. This is done by leaning on a simple and non-dialectical opposition: on one side, there is the 'Apollonian' element, especially linked to the notion of 'abstraction' (having a central position in Xenakis), to his vision of 'arts/sciences alloys' (a beautiful theory about the relationship between music and the sciences), and to the concept of 'formalization' (not a homogenuous concept in Xenakis). On the other side, there is the 'Dionysian' element, referring to the complexity of Xenakis' inspiration, to the underlying view of nature, and to the search for immediate expression. The paper finally discusses the Xenakis' notions of time and space, and his emphasis on creativity, two subjects that seem in a way to go beyond the Appollonian/Dionysian opposition and to point to an inner unity proper to the Xenakis' world.

In the Appendix to the paper, the reader may find detailed bibiliographical annotations on Xenakis' writings (books, papers and interviews).
\end{abstract}

\section{The movements of thought of an 'artist-conceptor'}

Xenakis belongs to a generation of composers (including Boulez, Schaeffer, Cage, and others) who published many books and articles. The relationship between his writings and his music, however, is not at all simple and direct. Many writings, focussing on the tools of formalization, have a relationship to some of his musical works. Yet, the reverse is not true: formalization, playing an important role in Xenakis' theories, is not as important, quantitatively, for his musical production. To analyze Xenakis' music, we should not limit ourselves to his theories: other theories should be constructed. However, the aim of the present paper is not to prove this 
statement true (on that, see two of my previous studies, Solomos, 1993; 1996), but to focuses on the writings themselves.

It is also important, in the perspective taken here, to note that we should not read Xenakis' writings just as a key to understand those (few) musical works into which they may provide some insight. To a large extent, his writings have their own autonomy. This is not to say that Xenakis should be seen as a music-theorist, at least not in a traditional sense, as such theorists disappeared during the $20^{\text {th }}$ century. Neither it means that he was a philosopher in the common sense of such word - to say so would be disappointing for professional philosophers, who would certainly send Xenakis back to school! The autonomy of his writings - as is also the case with other composers - is similar to the autonomy of the writings by artists like Kasimir Malevich, among others, i.e. the writings of a new kind of artist appeared in the $20^{\text {th }}$ century, whom we could define, using Xenakis' own terms, as 'artist-conceptor' (Arts/Sciences. Alliages, 13; Arts/Sciences. Alloys, 3). ${ }^{1}$

The aim of this paper is, then, to understand how this autonomy works. By reconstructing the unity of Xenakis' intellectual thought, I suggest that his though, while not belonging to an intellectual tradition as would be the case with pure philosophical thought, is nevertheless consistent in itself, because it does not necessarily function as a springboard for composition, i.e. as a premise to the materialization of musical thought.

Xenakis had many writings published in the 1950s and 1960s, in a time when much interesting theoretical work was done in the area of contemporary music. After that period, his writings are less developed, or at least develop issues already elaborated in earlier publications of his. Two reasons may explain this. First, in later years he created fewer and fewer theories. Secondly, in many regards, in later years he comes closer and closer to the more traditional kind of artist, an 'artist-artisan' (as constrasting to 'artist-conceptor'). Clearly, though, he did not abandon intellectual thought: in the last decades, he sometimes elaborated very important general issues which in the end allow a more global characterization of his intellectual universe.

To reconstruct the autonomy of Xenakis' writings, I wouldn't take a historical perspective. Of course, he changed a lot through the years (the already mentioned break in the 1970s is an example), but even so, important recurrent features - 'invariables' - persist in his writings. Such 'invariables' are not like theses firmly stated once and for ever, and should not be understood as a dogmatic element. For instance, one may be tempted to gather all of Xenakis' writings under his vision of 'alloys of arts/sciences', yet ultimately that reveals impossible,

\footnotetext{
1 In this paper, Xenakis' writings are considered as sources, not references, and are quoted according to the following conventions: a) books: title (in italics); b) articles: date and title (if article is also included in a book, the title of the book follows); c) interviews: interviewer and date. Normal references, instead, follow the conventions of the Journal of New Music Research.
} 
because he addressed himself to the alliance of art and science especially during the 1970s, while in the 1960s he had spoken more particularly of 'formalization' and 'axiomatization', and later, in the 1980s, payed instead very little attention to all such issues, and to the overall relationship between music and science. The invariables I am referring to are found in ideas first appeared in earlier years and then surprisingly developed in later decades.

In other words, these invariables are movements of thought that spring out in several texts written through the decades. To understand them, I will focus on a non-dialectic and very flexible opposition. We will try to refer such movements of thought to either terms of the opposition. This opposition itself is clearly observed in Xenakis' music, and maybe was also a characteristic of the man: to name it in a simple way, I will borrow the classical duality from early Nietzsche (The birth of tragedy): 'Apollonian' vs. 'Dionysian'. In my observations below, I match issues found in Xenakis' writings against such terms. In the last section of the paper, finally, I will turn to aspects of Xenakis' thought that seem to go beyond that opposition.

\section{THE APOLLONIAN XENAKIS}

\section{Abstraction}

The Apollonian Xenakis reveals himself first in his extraordinary propensity for abstraction. In early writings, Xenakis insisted on the necessity of abstraction as a goal of all modern thought. That was already clear in the 1959 article Notes sur un 'geste électronique', where Xenakis evoked the "steps towards abstraction" made in modern physics, mathematics and philosophy (1959, Notes sur un 'geste électronique', 25; Musique. Architecture, 143).

In Xenakis, 'abstraction' often means a tendency towards conceptualism, but in a broader sense than 'conceptual art', and closer to a simple kind of Platonism. "From now on, a musician should produce global philosophical theses [...], combinations of structures (forms) and sound matter", concludes an important article of his (1965, La voie de la recherche et de la question, 36; Kéleütha, 74). Elsewhere, he wrote that music is " $a$ sonorous fixation of virtualities of thought, of cosmological, philosophical theses" (1969, Structures universelles de la pensée musicale, 173). He adopted Varèse's idea - an idea that Varèse in turn had borrowed from HoeneWronsky - that "music is the solidification of the intelligence which is in the sounds" (Varèse, 1983: 115). In Xenakis' terms: “[...] the qualification 'beautiful' or 'ugly' makes no sense for sound, nor for the music that derives from it; the quantity of intelligence carried by the sounds must be the true criterion of the validity of a particular music" (Musiques formelles, 10; Formalized Music, IX). 
It is through the operation of abstraction that Xenakis addressed musical problems and formulated entirely new concepts. Some of these concepts belong to the sciences: 'density', 'determinism/indeterminism', ‘continuity/discontinuity', etc. Others are more philosophical: 'identity/non-identity', 'law' (rule), etc. The most far-reaching concept Xenakis elaborated in the 1960s, and never abandoned since, is perhaps the famous dichotomy between 'outside-time' and 'in-time'. To be precise, the first time he expressed this notion was in the context of the symbolic logics used for composing the piano piece Herma, where implicit was a threefold distinction: 'outside-time', 'temporal' and 'in-time' (see Musiques formelles, 191; Formalized Music, 160-161). But then he soon refined this concept by keeping it to a simple dichotomy: "We must distinguish two natures: intime and outside-time. That which can be thought of without changing neither with 'before' or 'after' is outsidetime. Traditional modes are partially outside-time; relationships or logical operations applied to classes of sounds, intervals, characters..., are also outside-time. Once a discourse contains 'before' or 'after', we are intime. Serial order is in-time, as is traditional melody. All music, in its outside-time nature, can be given in an instantaneous [...] way. Its in-time nature is the relationship between its outside-time nature and time. As a sound reality, purely outside-time music does not exist; pure in-time music exists, it is rhythm in its pure state" (1965, La voie de la recherche et de la question, 34; Kéleütha, 68).

That basic dichotomy remained essential in Xenakis' later work, but with an important shift in perspective: he increasingly insisted on 'outside-time' structures. In the beginning of the 1980s, he said: "Whatever we think is, by definition, outside-time because it is in our memory and doesn't disappear with the passage of time (unless we forget it). We have no power over the time-flow but we feel it passing: the notion of time is also outside-time" (interviewed by Varga, 1996: 83). It could be argued that Xenakis' implicit aim had always been, since the beginning, to insist on outside-time structures. In an important article from 1967, he maintained that Western music across the centuries renounced outside-time structures more and more, and that it is important today to reinvent them (1967, Vers une métamusique; Musique. Architecture, 58-59; Formalized Music, 193-194).

Abstraction can be referred to a major xenakian credo, namely his faith in the universalism of structural order. Xenakis developed his first theories in the 1950-60s, in a time when 'structuralism' was a predominant intellectual view. We could consider his search for outside-time structures as a paradoxical gesture leading backwards in history - this is discussed in (Solomos, 2002), where I show how was it that, in the 1980s, Xenakis focused almost exclusively on pitch scales. But we may also argue, in a different view, that his universalistic notion of 'structure' was very closely related to his time, being somehow equivalent with Lacan's 'unconscious', 
with the notion of 'myth' as clarified by Lévi-Strauss, or with the mathematical structures defended by the Bourbaki mathematicians.

Xenakis liked to present his music as a kind of 'generalization' of music of the past, even of music of non-Western cultures. For instance, he considered that stochastic music encompasses dodecaphonism and serialism (see 1962, Problemy mojej techniki kompozytorskiej, 27, 3; Musique. Architecture, 29). Later, he considered 'group theory' as a tool allowing for such a generalization, and used it for some of the music he composed in the 1960s (we must not forget that, in those years, mathematicians seeking for structural universalism used group theory as their main tool - see, for example, Ullmo, 1969: 255-261). For instance, speaking of the difference between 'transversal musicology' (today, musicology) and 'comparative musicology' (today, ethnomusicology), he added: "Because of the universality of the group structure of sound characteristics, the two branches of musicology will have [...] to adopt modern methods of investigation. [...] This means that the theses developed here must necessarily create a link of past and present music, of distant and close music, and unify the musical expressions of all times and all countries in a most vital, universally fertile view" (1965, La voie de la recherche et de la question, 36; Kéleütha,73-74). With his 'sieve theory' - the ultimate derivation of his personal use of group theory - Xenakis finally tried to achieve this structural universalism. For him, this theory enables one to reconstruct all existing scales and to invent new ones.

Xenakis' universalism is one of a structural order. His search for something that is invariable is not a kind of 'essence' or '(Platonic) Idea'. He is not searching for an immutable order abolishing differences and preventing change. In an important passage where he connected universalism and abstraction with the definition of music as 'solidified intelligence', he stated: "The worlds of classical, contemporary, pop, folk, traditional, avant-garde, etc., music seem to form unities unto themselves; sometimes closed, sometimes intersecting. Not only do they present extraordinary deviations, rich in new creations, but also fossilizations, ruins, and wastes, all in continuous formations and transformations, much like clouds - so distinct yet so ephemeral. This can be explained with the proposition that music is a sociocultural phenomenon; therefore, subordinate to a given moment in history. Yet we can distinguish the parts which are more invariable that others and which then form materials of hardness and consistency resulting from various epochs of civilization; materials which move in space, have been developed, put into use, and have followed the course of ideas, colliding one against the other, influencing and annihilating one another, mutually fecundating. But what is the essence of these materials? This essence is man's intelligence, in some way solidified. Intelligence which searches, questions, infers, reveals, foresees - on all levels. Music and the arts in general seem to be a necessary solidification, materialization of this 
intelligence. Naturally, intelligence, although humanly universal, is diversified by the individual, by talent, which distinguishes one individual from others" (Musique. Architecture, second edition, 181; Arts/Sciences. Alliages, 11-12; Arts/Sciences. Alloys, 1).

Among the practical consequences of Xenakis' propensity for abstraction, was his search for a synthesis of the arts. With his Polytopes, he was not looking for a fusion of different arts, but only their superposition: the Polytopes provided an example of the summation of several artistic domains, as in fact Xenakis was not so much interested in the arts themselves, but in the senses particularly involved in each of them (Solomos \& Raczinsky, 1999). For him, it is possible to superpose sense perceptions because, notwithstanding their obvious differences, senses coincide on a deeper level: there is not such a thing like a "correspondence or an equivalence between the expressions, for instance, of vision and hearing [...] The miracle of the equivalence is happening behind eye or

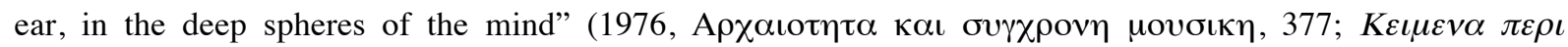

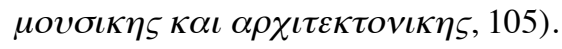

\section{Arts/Sciences, Alloys}

Abstraction and the need for structural universalism led Xenakis to that which remains his major contribution to music: the use of scientific concepts and tools in composing. Speaking of his early years, he explained: "I became convinced - and I remain so even today - that one can achieve universality, not through religion, not through emotions or tradition, but through the sciences. Through a scientific way of thinking" (interviewed by Varga, 1996: 47). However, on this point we should be very careful: Xenakis was not an old-fashioned positivist, indeed he added: "[b]ut even with that [scientific way of thinking], one can get nowhere without general ideas, points of departure. Scientific thought is only a means with which to realize my ideas, which are not of scientific origin. These ideas are born of intuition, some kind of vision" (interviewed by Varga, 1996: 47). It was thought and abstraction that led Xenakis to science, not the reverse.

In the early years of his work, Xenakis often argued that art (music) tags behind scientific evolution. In the 1970s, he even sketched historical timetables illustrating this in detail (Musique. Architecture, second edition, 192). Probably this caused many to view Xenakis as an old-fashioned positivist. However, that would be clearly a wrong view. If anything, Xenakis created those timetables most probably when he prepared materials for his Ph.D. (thèse sur travaux), in 1976, but then soon forgot about them. The essential point is a much more vital relationship between art and science: "[...] nothing prevents us from foreseeing new relationship between the arts and sciences, especially between the arts and mathematics; where the arts would consciously 'set' 
problems which mathematics would then be obliged to solve through the invention of new theories" (Musique. Architecture, second edition, 183; Arts/Sciences. Alliages, 14; Arts/Sciences. Alloys, 3).

Xenakis gave his thesis dissertation a very significant title: arts/sciences, alloys. As I mentioned above, it would be unfair to discuss all of his work by forcing it under this heading exclusively (he used those words only few times). Still, it was certainly a beautiful and significant way for him to express his debts to the sciences: if an art-science were to exist, this would be an 'alloy'. More precisely, it would be 'alloys', in the plural, i.e. not a perfect synthesis, nor a fusion. It was precisely in discussing this notion that Xenakis came to his definition of 'artist-conceptor': “[...] it seems that a new type of musician is necessary, an 'artist-conceptor' of new abstract and free forms, tending toward complexities, and then toward generalizations on several levels of sound organization. [...] The artist-conceptor will have to be knowledgeable and inventive in such varied domains as mathematics, logic, physics, chemistry, biology, genetics, paleontology (for the evolution of forms), the human sciences and history; in short, a sort of universality, but one based upon, guided by and oriented toward forms and architectures" (Musique. Architecture, second edition, 183-184; Arts/Sciences. Alliages, 13-14; Arts/Sciences. Alloys, 3).

Because mathematics is fundamental to it, the notion of 'art/sciences, alloys' could be seen as a Pythagorean credo. Yet, Xenakis' use of mathematics raises a lot of problematic questions. Mathematicians read Formalized Music often with some disappointment: there's no mathematical theory, just applications - often very problematic applications (none of the documented implementations is without many deviations from the corresponding theory ${ }^{2}$ ). Xenakis expressed himself very clearly on this issue: "I am [...] a user of mathematics" (interviewed by Bourgeois, 1969: 34). Accordingly, we should speak less of a Pythagorean mindset than of an inversion of the Pythagorean mindset: Pythagoras 'invented' mathematics by studying music, while Xenakis sometimes invented his music by studying and using mathematics.

Furthermore, we should not overvalue Xenakis' use of mathematics, for three reasons. First, he was deeply inspired by mathematics only in the 1950s and 1960s. In 1984 he was asked: “Mathematics don't interest you any more?", and answered: "It was an idea. Today, perhaps we need other ideas, more violent, stronger ones" (interviewed by Rey, 1984: 40). Second, as we'll see, another science-related source of inspiration was at

2 These deviations have generated significant commentaries. It has often been said that, because he forced his calculations towards idiosyncratic arrangements of, say, pitch or rhythm data, thereby disregarding the precise results of calculations, Xenakis 'remained an artist'. Such considerations may not be wrong in themselves, and yet fail to make the point. Those deviations were due to either Xenakis' arbitrary decisions that can hardly be accounted for as 'matters of taste', or his mistakes in the calculations themselves, or in their mapping to musical parameters (see Solomos, 1993: Chapter 13; and Solomos, 2000). 
least as important for his earliest compositions, i.e. the natural sciences, physics in particular. And third, in the notion of 'arts/sciences, alloys' mathematics do play a fundamental role, but maybe not in a central position. The already quoted sentence on the 'artist-conceptor' concludes: "Moreover the time has come to establish a new science of 'general morphology' which would treat these forms and architectures within these diverse disciplines in their invariant aspects and the laws of their transformations which have, in some cases, existed for millions of years. The backdrop for this new science should be the real condensation of intelligence; in other words, an abstract approach, free form anecdotes of our senses and habits" (Musique. Architecture, second edition, 184; Arts/Sciences. Alliages, 14; Arts/Sciences. Alloys, 3). Such was his propensity for abstraction: for Xenakis, the most abstract human endeavour, i.e. mathematics, was not enough.

\section{Formalization}

In the 1960s, Xenakis used another word, 'formalization'. This became widely known, so much so that many are tempted to use this term for characterizing all of Xenakis' thought. It is not difficult to explain the success met by the idea of a 'music formalization', if we just think that the utilization of new technologies (the computer) leads quite naturally to look for formalizable representations of all that was traditionally codified in implicit ways. However, we have to reduce the role of formalization by Xenakis. On one hand, it helps understanding only a (very) small part of his music. On the other, in his writings, which are the subject of this article, it is not a at all homogenous notion, as Xenakis used it with at least three meanings.

The historical book Musiques formelles refers to 'formalization' in its title, but in the book we find it very rarely. We find it in the Introduction and the Conclusion to the book. In the Introduction we read: "This abstraction and formalization has found, as have so many other sciences, an unexpected and, I think, fertile support in certain areas of mathematics. It is not so much the inevitable use of mathematics that characterizes the attitude of these experiments, as the overriding need to consider sound and music as a vast potential reservoir in which a knowledge of the laws of thought and the structured creations of thought may find a completely new medium of materialization, i.e., of communication" (Musiques formelles, 9; Formalized Music, IX). In the Conclusion we read: "formalization and axiomatization constitute a procedural guide, better suited to modern thought. They permit, at the outset, the placing of sonic art on a more universal plane. Once more it can be considered on the same level as the stars, the numbers, and the riches of the human brain, as it was in the great periods of the ancient civilizations" (Musiques formelles, 212; Formalized Music, 178). 
From these lines, it seems that the meaning of 'formalization' is quite broad, and could even be the same as 'abstraction'. However, Musiques formelles especially focuses on practical implementations, so it is not surprising to see that the issue of 'formalization' is not further developed in conjunction with 'abstraction'. In the 1960s, Xenakis preferred the term 'axiomatization', in the sense of mathematical axiomatics (see, for instance, his 1966 paper, Zu einer Philosophie der Musik / Toward a philosophy of Music; see also Musique. Architecture, 84-92, and Formalized Music, Chapter VIII). Both terms almost completely disappeared from his writings after the 1970s. I would say that Xenakis rarely used the word 'formalization' because its general principle, as already observed, is (mathematical) axiomatization; and while mathematical axiomatization certainly stimulated his imagination, we should admit that he was pragmatic enough to feel that this was not a particularly fertile path for practical developments in music - the only exception is Nomos alpha and his article about it (the just mentioned $\mathrm{Zu}$ einer Philosophie der Musik / Toward a philosophy of Music).

On the other hand, there's another term found in Musiques formelles, which may shed some light on a second meaning of formalization: 'mechanism'. Xenakis used it in his earlier writings and continued to use it in later years. Here is an 'invariable' in his writings. Recently, it has been argued that the first proposed title for Musiques formelles was Mécanisme d'une musique (Kanach, 2001). Even if the term 'mechanism' is rarely used in Musiques formelles it is important because it refers to the practical issues of formalization. While the general idea of 'formalization' as synonymous with mathematical axiomatization may not have practical aspects, the idea itself of 'formalization' has a practical goal. In the book, Xenakis used the word 'mechanism' when dealing with stochastic composition with computers: "[...] everything that is rule or repeated constraint is part of the mental machine. A little 'imaginary machine', Philippot would have said - a choice, a set of decisions. A musical work can be analyzed as a multitude of mental machines. A melodic theme in a symphony is a mold, a mental machine, in the same way as its structure is. These mental machines are something very restrictive and deterministic, and sometimes very vague and indecisive. In the last few years we have seen that this idea of mechanism is really a very general one. It flows through every area of human knowledge and action, from strict logic to artistic manifestations. Just as the wheel was once one of the greatest products of human intelligence, a mechanism which allowed one to travel farther and faster with more luggage, so is the computer, which today allows the transformation of man's ideas" (Musiques formelles, 164; Formalized Music, 132).

If we refer the notion of 'mechanism' to the initial words comprised in this quotation, 'rule' and 'constraint', we finally get to that which can be seen as a practical goal of Xenakis' formalization efforts: the construction of a kind of 'black box', so to say, which may be in itself able to produce a whole composition only 
based on some input data. It's with this notion in mind that we can understand Xenakis' extraordinary research into the 'fundamental phases of a musical work', and his search for a 'minimum of constraints' in the composition of Achorripsis (1962, Stochastische Musik / Stochastic Music; Musiques formelles, 33-36; Formalized Music, 22-24). To be able to define the smallest possible set of constraints would mean to be able to explain the rules of composition, i.e to design and build a mechanism able to compose a musical work. The ST computer program (early 1960s) and the GENDYN program (early 1990s) are such mechanisms. Describing the latter, Xenakis in the 1990s used almost the same words he had used 30 years earlier to describe the composition of Achorripsis: “[...] the challenge is to create music, starting, in so far it is possible, from a minimum number of premises but which would be 'interesting' from a contemporary aesthetical sensitivity, without borrowing or getting trapped in known paths" (1991, 'More Thorough Stochastic Music; Formalized Music, 295).

A third meaning of 'formalization' may be simply: 'use of mathematics'. Now, while use of mathematics is far from explaining all of Xenakis' music, it must be recognized a central position in his writings, especially those from the 1950s and 1960s. The present paper is not the proper place for a commentary of those writings in particular. However, it can be useful to provide the reader with a complete chronological list of Xenakis' 'theories' (in quotes, as they represent musical implementations of mathematical theories and formulas), with the related writings where they were discussed:

1. 'Stochastic' (utilization of probability functions for macrocomposition, i.e. for instrumental music; related xenakian notions include 'free stochastic', 'Markovian stochastic', and the ST program):

a) Musiques formelles, Chapters I, II et IV (Formalized Music, Chapters I, II, III, V);

b) early articles providing the basic text later expanded in the chapters of Musiques formelles just mentioned: 1956, Wahrscheinlichkeitstheorie und Musik; 1958, Auf der Suche einer Stochastischen Musik / In search of a Stochastic Music; 1960-61, Grundlagen einer stochastischen Musik / Elements of Stochastic Music; 1961, La musique stochastique: éléments sur les procédés probabilistes de composition musicale;

c) other articles, including: 1958, Les trois paraboles (Musique. Architecture, 16-19); 1962, Eléments sur les procédés probabilistes (stochastiques) de composition musicale (Kéleütha, 54$66)$.

2. 'Game theory':

Musiques formelles, Chapter III (Formalized Music, Chapter IV). 
3. 'Symbolic logics':

Musiques formelles, Chapter V (Formalized Music, Chapter VI).

4. 'Group theory':

1966, Zu einer Philosophie der Musik / Toward a philosophy of Music (Musique. Architecture, 71119; Formalized Music, Chapter VIII).

5. 'Sieve theory':

1965, La voie de la recherche et de la question (Kéleütha, 67-74); 1966, Zu einer Philosophie der Musik / Toward a philosophy of Music (Musique. Architecture, 71-119; Formalized Music, Chapter VIII); 1967, Vers une métamusique (Musique. Architecture, 38-70; Formalized Music, Chapter VII); 1981, Le temps en musique (Kéleütha, 94-105; Formalized Music, Chapter X); 1990, Sieves (Formalized Music, Chapters XI and XII; Kéleütha, 75-87).

6. 'Dynamic stochastic synthesis' (utilization of probability distribution functions for microcomposition, i.e. synthesis of sound as finally implemented the GENDYN program):

1977, Nouvelles propositions sur la micro-structure des sons (Arts/Sciences. Alliages, 139-149; Formalized Music, Chapter IX); 1981, Les chemins de la composition musicale (Kéleütha, 15-38); 1991, Dynamic Stochastic Music (Formalized Music, Chapter XIII); 1991, More Thorough Stochastic Music (Formalized Music, Chapter XIV).

To this list, we should add other 'theories' that Xenakis utilized in actual compositional work, but that he explained only informally:

7. 'arborescences':

in interviews with Varga (1996: 87-89) and Delalande (1997: 92-97).

8. 'brownian motion'

in the interview with Varga (1996: 90).

9. "cellular automata"

in the interview with Varga (1996: 197-198).

Finally, let us add to this list Xenaki's technological invention:

10. UPIC (Unitè Polyagogique Informatique du CEMAMu)

The only article on this actually signed by Xenakis is: 1992, The New Upic System (Formalized Music, 329-334). This article was "freely inspired by a similar paper [...] written by Gérard Marino, Jean-Michel Raczinski and Marie-Hélène Serra” (Formalized Music, 329). 


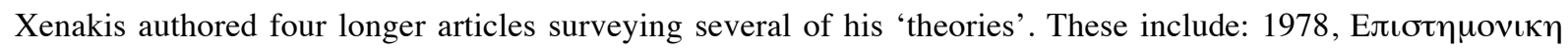

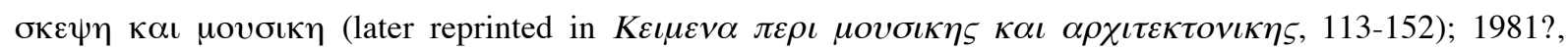
Problématiques scientifiques et compositions musicales; 1982, La composition musicale est à la fois dépendante et indépendante de l'évolution technologique des systèmes analogiques ou numériques; 1996, Determinacy and Indeterminacy.

\section{THE DIONYSIAN XENAKIS}

\section{On inspiration}

The Dionysian element is much more apparent in Xenakis' music than his writings. More precisely, in his music we find an extraordinary balance between the Apollonian and the Dionysian, while in his writings the Apollonian element is predominant. Still, the Dionysian is present, especially in interviews.

It should be emphasised that the sciences are for Xenakis, basically, a source of inspiration. While formalization - in general: the ability to explain musical processes, similar to the ability of science to explain its own objects of study - was very important to him, we should not neglect that the sciences - as methods of knowledge themselves supported by a strong imagination - had a strong influence upon Xenakis in much the same way as did poetry, dreams, etc. He could have quoted Varèse: "I often borrow my titles from mathematics or astronomy because these sciences stimulate my imagination [...]. I find more musical inspiration in the contemplation of the stars - especially through a telescope - and in the high poetry of a mathematical demonstration than in the most sublime story of human passions" (Varèse, 1983: 41). In a sense, confronting the fantastic advances of the $20^{\text {th }}$ century science, Xenakis was like a child dreaming of a telescope. Recently more and more musicians have followed a similar path. The theory of relativity and quantum mechanics, the Big Bang theory and antimatter, chaos and fractals, etc. inspire them at least as much as a well composed fugue or "the most sublime story of human passions".

On the one hand, Xenakis worked out many of his 'theories' rather poetically, metaphorically, in analogy with scientific concepts. For instance, in a famous 1955 article, the wave/particle duality of quantum physics provided him with a metaphor suggesting the search for musical phenomena in some way equivalent to it (1955, La crise de la musique sérielle, 3 ; Kéleütha, 41).

On the other hand, Xenakis' musical and/or general intuitions (non-scientific ones) found their way to materialization by means of tools borrowed from the sciences. An example is the notion of 'sound mass', and all features of statistic behaviour in sound. 
The two ways are combined. Sometimes, inspiration is 'scientific': new concepts of science give birth to such strong and beautiful visions, that one dreams to materialize them in music - a transfer which can in turn engender new, purely musical, ideas, since any transfer from science to music comes with creative discrepancies. Elsewhere, musical or general ideas rely on tools belonging to the sciences for their realisation. To a large extent, the two directions are intermingled, so much so that it may be quite difficult to distinguish between them. Concerning 'sound masses' and statistical behaviours in Xenakis' music, for example, we should consider that they stemmed from direct personal experiences of either human phenomena - street demonstrations - or natural phenomena - like rain, cicadas, etc. (see his beautiful text on the origins of the idea of stochastic composition: 1961, La musique stochastique: éléments sur les procédés probabilistes de composition musicale, 299; Musiques formelles, 19; Formalized Music, 8-9). We should also consider that such concepts are related, too, to purely musical intuitions: while in the few compositions based on 'group theory' there is an obvious transfer from mathematics to music, in other cases - for instance the musical use of 'brownian motion' - that is dubious ${ }^{3}$.

\section{An 'orgiastic' nature}

Sure, in Xenakis, formal models meet with nature at one level or another. In his work, references to nature are frequent. Recalling the steps that had led him to stochastic composition, Xenakis said: "The first step was the control of mass events and the recognition of laws which govern nature" (interviewed by Varga, 1996, 76). In a sense, for Xenakis there was no duality of the kind 'nature vs. culture'. The 'cosmos' or 'universe' (ultimately: Nature), was for him the only existing thing. This is why he could often appear as a naturalist. Consider his terminology: 'sound clouds' (very often used in his writings), 'galactic configurations' (in the introductory notes to the Pithoprakta score), 'ionized atoms' (as in his 1966 article on Nomos alpha: Zu einer Philosophie der Musik / Toward a philosophy of Music; see Musique. Architecture, 104; Formalized Music, 222). Concerning the Polytopes he wrote: “To be sensitive to luminous phenomena, above all natural ones: lightning, clouds, fires, sparkling sea, sky, volcanoes... To be much less sensitive to luminous games of pictures, even abstract ones, to stage settings, to opera. To prefer natural shows not man-made ones. To prefer the vertigo created by the abyss of the open sky, when we loose our head and forget the ground where our feet stand" (1982, Polytopes: 218).

\footnotetext{
3 Since there exist only few xenakian 'theories', we can make some possibly exhaustive hypotheses: (1) 'theories' inspired by human experiences, or contemplation of natural phenomena, also related to musical ideas, and which have been realized by borrowings working tools from science: this is only the case of 'stochastic music'; (2) 'theories' directly inspired by science: 'game theory', 'symbolic logics', 'group theory', and 'cellular automata'; (3) somewhere in between the former two cases are 'sieve theory' and the 'dynamic stochastic synthesis',
} 
Naturalistic metaphors often play a central role in science-music transfers. The most famous is perhaps the metaphor comparing an isolated sound to a molecule. It was this metaphor that opened to the introduction of probability functions in composition. In 1958 Xenakis wrote: "Let's identify isolated sounds, for example: pizz., with molecules; we obtain an homomorphic transformation from the physical field to the sound field. The individual movement of sounds no longer matters" (1958, Les trois paraboles; Musique. Architecture, 19).

This is the reason why natural sciences, especially physics, play a crucial role in Xenakis' work. While composing tools were often referred to mathematics (formalization), his most recurrent source of inspiration was natural sciences. The most recurrent scientific reference, and also the earliest one, i.e. that of probability functions, points to an area of research born of physics. Xenakis used probabilities ('stochastics', 'brownian motion', 'dynamic stochastic synthesis') in different periods of his career, in an approach that had a predominant role in (few) thoroughly formalized musical works, and in passages of some others. Besides, as the probabilistic conception resulted from a scientific vision of a considerable impact (which is not the case with group theory, a.o.), its compositional use is perhaps the only instance where the arts/sciences alloys work perfectly.

Let's examine three moments in Xenakis' itinerary with probability theory.

First 'stochastics', that is, probability functions used in macrocomposition. There, Xenakis realized his vision of massive, statistical phenomena - human, natural or sonic - with probability distribution functions. The underlying scientific vision stems from a branch of physics born in the $19^{\text {th }}$ century, thermodynamics: “[...] there are billions of molecules. [...] Boltzmann and Maxwell had the marvellous idea of resorting to the probability theory. They pointed out that, in a given quantity of gas, it was the average density of movement that counted: the average energy of the particles was in connection with the temperature of the gas. If, therefore, the gas has a greater energy - that is, if the particles hit each other faster than before - then the temperature would also be higher and the pressure on the wall of the tank would increase. Through a very simple inference they came to the conclusion that energy was determined by the Laplace-Gauss probability distribution law, which was discovered nearly a century earlier" (interviewed by Varga, 1996: 78).

The second reference to probabilities is related to work made in the 1960s, then further developed in the 1970s with 'brownian motion': Xenakis simply mapped probabilistic curves of sound pressure to some aspects of instrumental writing (Solomos, 2001a). These curves were obtained as 'random walks' controlled with some probability function. For Xenakis, the latter term, random walk, is synonymous with brownian motion. Yet, while the first is related to a mathematical abstraction, the latter refers to the "processes of chaotic movements of small particles suspended in a liquid or a gas, which are the result of their collision with the molecules of the 
environment' (Encyclopedia of Mathematics, vol.1, London, Kluwer Academic Publishers, 1993: 483). Xenakis used the term 'brownian motion' more frequently than 'random walks', probably because he was seduced by the concrete, physical phenomenon.

The third reference in this line is connected with the hypothesis of the granular nature of sound. Xenakis worked out this, in conjunction with stochastics, in composing Analogique A et B (1958-59). In his writings, we find one only page on this subject: "All sound is an integration of grains, of elementary sonic particles, of sonic quanta. [...] Hecatombes of pure sounds are necessary for the creation of a complex sound. A complex sound may be imagined as a multi-colored firework in which each point of light appears and instantaneously disappears against a black sky. But in this firework there would be such a quantity of points of light organized in such a way that their rapid and teeming succession would create forms and spirals, slowly unfolding, or conversely, brief explosions setting the whole sky aflame. A line of light would be created by a sufficiently large multitude of points appearing and disappearing instantaneously" (1960-61, Grundlagen einer stochastischen Musik / Elements of Stochastic Music; Musiques formelles, 61; Formalized Music, 43-44) ${ }^{4}$. The granular representation of sound has a very important role in the developments of electronic music. Today many composers (including Horacio Vaggione, Curtis Roads, Agostino Di Scipio, and many others) are, not unlike Xenakis, more attracted by the concept of a whirlwind of sonic particles than by the linear additive synthesis paradigm.

'Hecatombes of pure sounds', 'multi-colored fireworks', 'brief explosions setting the whole sky aflame', 'processes of chaotic movements of small particles suspended in a liquid or a gaz', sounds made of 'billions of molecules' and gases with 'great energy' - all such images converge: Xenakis' image of Nature is the one supplied by modern science. It is far removed from, say, the naturalistic views proper to Romanticism or Taoism (this is fundamental to understand Xenakis' 'naturalism'). We have learned to call this kind of nature 'chaotic', but Xenakis could refer to chaos theory - which became well-established in scientific circles during 1970s - only later in his work (see the Preface to the 1992 edition of Formalized Music, XII-XII). This considered, and considering, too, that Xenakis' references to ancient Greece addressed not the classical age but the archaic age (the age of Gods and Titans fighting among them), I think we could speak of an orgiastic view of Nature. Commenting his orchestral piece Terretektorh, Xenakis wrote: "The listener will be [...] either perched on the crest of a mountain surrounded by a terrible storm or on a rickety skiff in the middle of violent sea or in a pointillist universe of sparks of sound, moving in compact or isolated clouds" (liner notes to the compact disc ERATO STU 70529). 


\section{The search for immediate expression}

And yet, is Xenakis' music really naturalistic? The figurative, descriptive appearance (cicadas, storms, etc.) was only a pretext for the composer, just as in Baroque music the descriptive attitude was only a starting point for composers to invent new sonorities. What is important is not the referent - the absent, referred-to element - but a sense of complete presence of sound: xenakian sonorities are directly addressed to the listener's senses. We may say that this music goes beyond the idea of representation. In his writings, he is very clear on this subject: he didn't say that he wanted to illustrate, represent, imitate natural phenomena, but, for instance, that his masses are 'sound clouds'. This music has an immediate impact on listeners, without leaning on language, figuration, code: in a way, by directly addressing the senses, its impact is the impact of a natural phenomenon.

In certain writings of his, Xenakis insisted on the sensorial dimension. His research, as he put it, "[...] is a question of touch, of the touch of sounds" (interviewed by Walter, 1968: 22). He refused to envisage music as language: "Music is not a language, it is not a message. [...] The impact that music produces often exceeds our rational methods of investigation. Movements are created inside you, you can be conscious of them or not, you can control them or not, they are in you" (interviewed by Lyon, 1974: 133).

In a way, Xenakis was searching for immediate expression, i.e. not mediated by signs or else. He once compared music with drinking wine (personal communication). And there we are really near to dionysism... But surprisingly enough, immediate expression may still resemble abstraction, as is clear in the following lines from 1975, answering a question on the expressive element of his music: "Expression is what [...] differentiates life and non-life. [...] But [...] you want to know if, in my scores, I search to exhibit, according to the traditional model, feelings like a dream, despair or joy. That is totally different. I consider that is useless. In the $19^{\text {th }}$ century, it could be like this because a codified musical language was based on social conventions, which were also recognised. Today, social conventions are destroyed, and new ones have not been constructed. This is why musical vocabularies have lost their meaning, their sense. From now on we have to understand, once again, music as an abstraction and, from there, to redefine it" (interviewed by Pauli, 1975: 304).

The quest for immediate expression may shed new light on statements made by the young Xenakis, for instance, in a 1961 text later published as the beginning of Musiques formelles: "Art, and above all, music has a fundamental function, which is to catalyze the sublimation that it can bring about through all means of expression. It must aim through fixations which are landmarks to draw towards a total exaltation in which the individual mingles, losing his consciousness in a truth immediate, rare, enormous, and perfect. If a work of art

\footnotetext{
${ }^{4}$ Whether Xenakis borrowed this hypothesis from Gabor or Einstein is discussed in (Di Scipio, 1998).
} 
succeeds in this undertaking even for a single moment, it attains its goal. This tremendous truth is not made of objects, emotions, or sensations; it is beyond these, as Beethoven's Seventh Symphony is beyond music. This is why art can lead to realms that religion still occupies for some people. But this transmutation of every-day artistic material which transforms trivial products into meta-art is a secret. The 'possessed' reach it without knowing its 'mechanisms'. The others struggle in the ideological and technical mainstream of their epoch which constitutes the perishable 'climate' and the stylistic fashion" (1961, La musique stochastique: éléments sur les procédés probabilistes de composition musicale, 294; Musiques formelles, 15; Formalized Music, 1).

\section{TIME AND SPACE. ORIGINALITY}

An immediate expression through a sense of a union with the whole Nature: this may be Xenakis' Dionysian aspect. In the end, we could say that in Xenakis' work (writings and music) Apollonian and Dionysian aspects are perfectly combined. For the young Nietzsche, sculpture was the Apollonian art par excellence, while music was the Dionysian: Xenakis was a musician, but, above all, he was a 'sound sculptor (Solomos, 2001b). And yet, probably a couple of issues raised in certain of his writings cannot be discussed within the boundaries of this non-dialectical opposition. I refer to the issue of time and space, and also to the idea of originality.

\section{Time and space: on energy}

In order to adopt concepts of thermodynamics, one must also adopt a vision where time is essential, as is clear in recent developments in physics. Xenakis acknowledged the centrality of non-measured time, i.e. the pure timeflow. He even thought of it almost like an equivalent to music itself: "When you use tools like paper, while writing and conceiving musical forms, you can think in terms of spatial qualities, but that is less important during composition itself. Music develops in time [...] Musical time can't be reduced to its chronometrical passing [...] The exact measurement, in seconds, of musical time and durations offers little interest [...] It is the interior of time which counts, not its absolute duration [...] Time is independently and simultaneously articulated by various musical events" (interviewed by Harley, 1994: 13). Xenakis made a difference between 'flow' and 'duration', meaning non-measured and measured time. Only the latter is reversible: “A duration is something that can be moved around within time, it is therefore reversible, commutative. [...] The difference between any two points is a concept which stems from comparisons and mysterious judgements I make about the reality of the temporal flow, which I accept a priori. The distance between the two points is what is then identified as a 
duration. I displace this duration anywhere; therefore, it is reversible. But the temporal flow itself is irreversible" (Arst/Sciences. Alliages, 105-106; Arts/Sciences. Alloys, 74-75).

In these lines, the phrase "mysterious judgements I make about the reality of the temporal flow, which I accept a priori" is crucial. Xenakis admits that he does not know what time is (time-flow). In one of the latest interviews, he said: "I never understood what is time. Time remains something mysterious for me. Time is everywhere, it rains, it snows ${ }^{5}$, it is part of nature. This is why I can not understand what time is" (interviewed by Corlaix and Gallet, 1998: 29).

That may explain why he focused more and more on measured time - time that can be constructed: "There is the temporal flow, which is an immediate given, and then there is metrics, which is a construction man makes upon time" (Arts/Sciences. Alliages, 136; Arts/Sciences. Alloys, 97). He often defined time (time-flow) as an empty blackboard: "Time could be considered as a blank blackboard, on which symbols and relationships, architectures and abstract organisms are inscribed" (1967, Vers une métamusique; Musique. Architecture, 58; Formalized Music, 192). There, time is an abstract dimension enabling one to ask the question of time in terms of construction. Therefore, when he said that time is the same as music, it would be 'measured time', not 'timeflow', that he meant. This sharply contrasts with the centrality of non-measured time in Bergson's philosophy (although Bergson's word for non-measured time was 'duration'). Xenakis is more interested in the possibility to make, build or construct something within time (or, upon time). We may even say: to construct time. It is no surprise, then, that during the 1960s and 1970s he had a strong interest in Jean Piaget: "Piaget's book provided me with my first justification that I was right to do calculations with time. He proved that the perception of time stopped developing at the age of twelve. Up until the age of six one can't see this process clearly, but between six and twelve I think there are three stages. He showed that time has an ordering structure and that time intervals can be added and permutated, and consequently that they have a group structure. I concluded from all this that time is nothing but a kind of structure. And because it is a structure it can be counted, expressed with real numbers, and shown as points on a straight line" (interviewed by Varga, 1996: 82-83).

In the 1960s, Xenakis spoke of 'amnesia'. The chapter of Musiques formelles devoted to 'symbolic music', begins as follows: "we shall begin by imagining that we are suffering from a sudden amnesia. ${ }^{6}$ We shall thus be able to reascend to the fountain-head of the mental operations used in composition and attempt to extricate the general principles that are valid for all sorts of music" (Musiques formelles, 185; Formalized Music,

5 The French word "temps" means both "time" and "weather". 
155). In a sense, we may say that Xenakis 'fighted' with time. And, anyway, we should not forget his notion that the temporal dimension also includes 'outside-time' structures: "Whatever we think is by definition outside time because it is in our memory and doesn't disappear with the passage of time (unless we forget it). We have no power over the time-flow but we feel it passing: the notion of time is also outside time" (interviewed by Varga, 1996: 83).

Elsewhere, Xenakis considered time as an epiphenomenon, and space as a more fundamental reality. On this, we should carefully look into Xenakis' only article explicitly devoted to the issue of time (1988, Sur le temps, then reprinted in Kéleütha, 94; Chapter X of Formalized Music is closely related to this article). The beginning reads: "Isn't time simply an epiphenomenal notion of a deeper reality? Thus an illusion that we unconsciously accept since our earliest years and even since the earliest, ancient ages?" (Kéleütha, 94). He made then the hypothesis that 'displacement' is a more fundamental notion, and added: "If the notion of displacement were more fundamental than that of time, one could undoubtedly reduce all macro and microcosmic transformations to extremely short chains of displacement" (Kéleütha, 94; Formalized Music, 256). Furthermore, mentioning to the experiment of "correlation of the movement of two photons emitted in opposite directions by a single atom" (Kéleütha, 95; Formalized Music, 257), he noted: "Now, this experiment could be a starting point for the investigation of more deeply seated properties of space, freed from the tutelage of time. In this case, could the 'nonlocality' of quantum mechanics be explained perhaps not by the hypothesis of 'hidden variables' in which time still intervenes, but rather by the unsuspected and extravagant properties of nontemporal space, such as ‘spatial ubiquity’, for example?” (Kéleütha, 96; Formalized Music, 257).

Yet, not even space seems to be the ultimate reality. Xenakis' preliminary conclusions, in fact, are as follows: "As space is perceptible only across the infinity of chains of energy transformations, it could very well be nothing but an appearance of these chains. In fact, let us consider the movement of a photon. Movement means displacement. Now, could this displacement be considered an autogenesis of energy, an energetic parthenogenesis of the photon by itself at each step of its trajectory (continuous or quantized)? This continuous auto-creation of the photon, could it not, in fact, be space?" (Kéleütha, 96; Formalized Music, 257-258, incomplete).

\footnotetext{
6 The word "suffering", in the published English translation, deviates a little from the original French. The latter reads: "nous commencerons par nous considérer brusquement amnésiques" (we shall start by considering ourselves suddenly amnesic).
} 
Energy: that could be the real thing which would make the Apollonian side of Xenakis lean towards the Dionysian side. Clearly, we may ask: what notion of energy, anyway? I shall leave this question open, but quote Xenakis in a most surprising discussion with the composer Morton Feldman:

“I.X. Yesterday we had a very good performance [Feldman's Trio]. Do you agree?

M.F. Yes!

I.X. Were you happy with it?

M.F. I'm neither happy or unhappy.

I.X. What?

M.F. I'm neither happy or unhappy with it.

I.X. What do you mean, why?

M.F. I thought it was just a little stiff.

I.X. You wanted more agitation?

M.F. No, I wanted them [the interpreters] to breathe with each other more naturally. Breathe rather than count.

I.X. But they counted correctly.

M.F. Yes, they counted correctly. Maybe that was it, that it was a little too mechanical in the counting. I.X. Well, no, I don't think that was the problem. I think I understand what you mean. Music is used as acoustical energy. The problem of composition is how to use that energy. Last night the energy wasn't there in a sense of an acoustical appearance. In the score it was there, from the combination of the sounds, the timbre, the rhythms, the length, and the timing of the piece. That is a completely different aspect. I was amazed by the fact that with so few notes you can produce that comprehension of things. I felt like a child because I write many notes” (Feldman \& Xenakis, 1988: 177).

\section{Originality}

Concerning energy, Xenakis spoke of 'autogenesis' and 'parthenogenesis' (see the above mentioned "energetic parthenogenesis of the photon"). His concern for originality is well known. In all his life, he always tried to renew himself: "Yes, originality is an absolute necessity for the survival of mankind. I will add that it is a necessity for the survival of the cosmos. Creation must exist in the universe" (1984, L'univers est une spirale, 88; Kéleütha 136). For him, creation = (absolute $)$ originality. In another 1984 article, he expressed his belief in "a universe open to a complete novelty that would continually appear and disappear in a truly creative whirlwind 
which starts from nothingness and disappears into nothingness. It is very important for the foundations of art as well for the destiny of humankind" (1984, Musique et originalité; Kéleütha, 111).

For Xenakis, "composing is a battle" (interviewed by Varga, 1996: 202) because it is "a struggle for existence. To be. If, however, I imitate the past, I do nothing, and consequently I am not. In other words, I am sure that I exist only if I do something different. The difference is the proof of existence, of knowledge, of participation in the affairs of the world" (interviewed by Varga, 1996: 50). It is clear here that creation should be not only parthenogenesis but: creation ex nihilo.

I think Xenakis' notion of 'originality' expressed something other than what it is commonly meant with that word. It was more an ontological issue. Xenakis liked to paraphrase Parmenides by saying: "For it is the same to be and not to be" (Parmenides had it, however: "For it is the same to think and to be"). He added: "Nothingness resorbs, creates. It engenders being" (Musiques formelles, 36; Formalized Music, 24). For Xenakis, the absence of strict causality meant absolute freedom, a world with no rules. Looking back to his initial work with stochastic music, he asked: "Can we conceive of anything with no rules? That is, no causality? Which means that no connection exists between phenomena, which in turn equates 'to be' with 'not to be'?", and also added: "That was the theory and to translate intro practice I thought of probabilities. Music that used only probabilities would be the extreme case of having rules that weren't rules" (interviewed by Varga, 1996: 167). That may explain why the use of of probability density functions was so important: it help him to conceive of a musical universe born of nothingness.

Creation ex nihilo is the cornerstone of the xenakian utopia. I write 'utopia', as Xenakis knew quite well that it may not turn into reality: "No one can create a new world. It's impossible to create something different no such example exists in the history of art. It's sad: we are prisoners of ourselves" (interviewed by Varga, 1996: 71).

To conclude, I should say I was always surprised by the fact that Xenakis though of his sentence 'For it is the same to be as not to be', that it was a paraphrase of Parmenides' 'For it is the same to think and to be'. Another Parmenides' sentence is just as famous: "The being exists, nothingness, on the contrary, does not exist". Why was he attracted by the first, and not by the latter - apparantly more strictly connected to his own work - is inexplicable. We have a long way to go in the attempt to understand and interpret the thought and mental universe of Xenakis. 


\section{Acknowledgements}

The present paper is a shorter version of a longer essay that will eventually appear in Italian, as the Postface to a volume of Xenakis' selected writings. The original French text will appear in the volume Formel/Informel edited by Antonia Soulez, Horacio Vaggione and Makis Solomos.

Sharon Kanach corrected the English draft. The guest-editor, Agostino Di Scipio, rewrote it totally, making it more comprehensible.

\section{References}

Di Scipio, A. (1998). Scienza e musica dei quanti acustici: l'eredità di Gabor, Il Monocordo, 6: 71-73.

Kanach, S. (2001). A propos de Musiques formelles. Une invitation à lire Xenakis. In (F.-B. Mâche, ed.), Portrait(s) de Iannis Xenakis. Paris, Bibliothèque Nationale de France: 201-213

Solomos, M. (1993). A propos des premières aeuvres (1953-69) de I. Xenakis. Pour une approche historique de l'émergence du phénomène du son. Ph.D., Paris, Université Paris 4

Solomos, M. (1996). Iannis Xenakis. Mercuès, P.O. Editions.

Solomos, M. (2000). Analyse et idéologie chez Xenakis, Sonus - Materiali per la musica contemporanea, 20: 87-96.

Solomos, M. (2001a). The unity of Xenakis' instrumental and electroacoustic music. The case of 'brownian movements', Perspectives of New Music, 39(1): 244-254.

Solomos, M (2001b). Sculpter le son. In (Mâche, F.-B., eds.), Portrait(s) de Iannis Xenakis. Paris, Bibliothèque Nationale de France: 133-142.

Solomos, M. ed. (2001c). Présences de Iannis Xenakis. Paris, CDMC.

Solomos, M. (2002). De la sonorité à la hauteur. Echelle et micro-intervalles chez Xenakis. Forthcoming.

Solomos, M., Raczinsky, J.M., (1999). La synthèse des arts à l'ère du multimédia. A propos du Diatope de Iannis Xenakis. In (J.Caullier, ed.) Le mélange des arts. Lille, Cahiers de la Maison de la Recherche de l'Université Charles-de-Gaulle-Lille, vol.3: 63-76.

Ullmo, J. (1969). La pensée scientifique moderne. Paris, Flammarion.

Varèse, E. (1983). Ecrits (edited by Louise Hirbour). Paris, Christian Bourgois. 


\section{APPENDIX. SOURCES (XENAKIS' WRITINGS)}

Note: this bibliography only includes writings quoted in this paper. A complete and commented bibliography (publications by and on Iannis Xenakis) is found in (Solomos, 2001c) and can also be freely downloaded from the website: www.iannis-xenakis.org.

\section{Books}

Musiques formelles. Monograph issue of La Revue Musicale, 253-254 1963. (Reprinted: Musiques formelles.

Paris, Stock, 1981.)

Musique. Architecture, Tournai, Casterman, 1971. (revised and extended edition 1976.)

Formalized Music, translation Christopher Butchers, G. H. Hopkins, John Challifour, Bloomington, University Press, 1971 (revised and extended revision compiled and edited by Sharon Kanach, Stuyvesant NY, Pendragon Press, 1992.)

Arts/Sciences. Alliages. Tournai, Casterman 1979. (Amercian translation by Sharon Kanach: Arts/Sciences.

Alloys. Stuyvesant NY, Pendragon Press, 1985.)

Kéleütha, edited by Alain Galliari, preface of Benoît Gibson, Paris, L’Arche 1994.

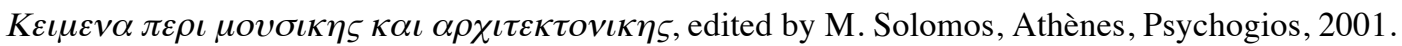

\section{Papers}

(1955) La crise de la musique sérielle, Gravesaner Blätter, 1: 2-4. (Kéleütha: 39-43.)

(1956) Wahrscheinlichkeitstheorie und Musik, Gravesaner Blätter, 6: 28-34. (Musiques formelles: 26-33;

Musique. Architecture: 9-15; Kéleütha: 46-53.)

(1958) Auf der Suche einer Stochastischen Musik / In search of a Stochastic Music, Gravesaner Blätter, 11-12:

98-111/ 112-122. (Musiques formelles, 36-51.)

(1958) Les trois paraboles (in Swedish), Nutida Musik, 4. (Musique. Architecture: 16-19.)

(1959) Notes sur un "geste électronique”, Revue Musicale, 244: 25-30. (Musique. Architecture: 143-150.)

(1960-61) Grundlagen einer stochastischen Musik / Elements of Stochastic Music (part I), Gravesaner Blätter

18: 61-83 / 84-105; (part II), Gravesaner Blätter 19-20: 128-139 / 140-150; (part III), Gravesaner Blätter 21:

102-111 / 113-121; (part IV), Gravesaner Blätter 22: 131-143 / 144-145.

(1961). La musique stochastique: éléments sur les procédés probabilistes de composition musicale, Revue d'Esthétique, 14(4-5): 294-318 (Musiques Formelles: 15-36; 52-53; 61; 137-139; 211-212). 
(1962) Eléments sur les procédés probabilistes (stochastiques) de composition musicale. In (Samuel, C. ed.)

Panorama de l'art musical contemporain, Paris, Gallimard: 416-425. (Kéleütha: 54-66.)

(1962). Problemy mojej techniki kompozytorskiej, Horyzonty Musyki, 1: 27,1 - 27,8.

(1962) Stochastische Musik / Stochastic Music, Gravesaner Blätter, 23-24: 156-168 / 169-184. (Musiques

formelles: 15-36, 52-53; 61; 137-139; 211-212.)

(1965) La voie de la recherche et de la question, Preuves, 177: 33-36. (Kéleütha: 67-74.)

(1966) Zu einer Philosophie der Musik / Toward a philosophy of Music, Gravesaner Blätter, 29: 23-38 / 39-52.

(Musique. Architecture: 71-119.)

(1967) Vers une métamusique, La Nef, 29 (Musique. Architecture: 38-70.)

(1969) Structures universelles de la pensée musicale. In Liberté et organisation dans le monde actuel (no editors credited), Paris, Desclée De Brouwer: 173-180.

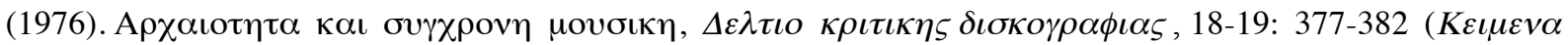

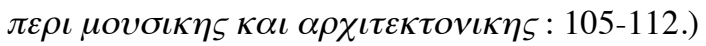

(1977) Nouvelles propositions sur la micro-structure des sons, Dossiers-Arts Plastiques, vol.1 (Formalized Music: 242-254.)

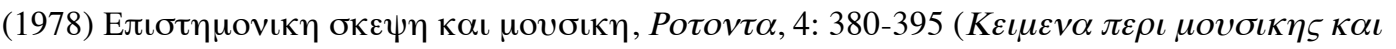

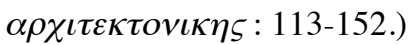

(1981) Les chemins de la composition musicale. In Le compositeur et l'ordinateur, Paris, IRCAM: 13-27. (Kéleütha: 15-38.)

(1981) Le temps en musique, Spirales, 10: 9-11. (Kéleütha: 94-105.)

(1981?) Problématiques scientifiques et compositions musicales. Text of a presentation delivered in a

Conference of the Académie Européenne des Sciences, des Arts et des Lettres. Date uncertain. Manuscript trascription made by unidentified writer (17 type-written pages).

(1982). La composition musicale est à la fois dépendante et indépendante de l'évolution technologique des systèmes analogiques ou numériques. Conférences des journées d'études. Festival international son et image vidéo, Paris, Société pour la Diffusion des Sciences et des Arts, 1982: 137-155.

(1982) Polytopes. In Le festival d'automne à Paris 1972-1982, Paris, Temps actuels: 218.

(1984) Musique et originalité, Phréatiques, 28: 62-66. (Kéleütha: 106-111.)

(1984) L’univers est une spirale, Le Nouvel Observateur, Mai 1984: 88-89. (Kéleütha: 136-138.) 
(1988). Sur le temps. In Redécouvrir le temps - vol.II (no editors credited), Université de Bruxelles: 193-200 Kéleütha: 193-200).

(1990) Sieves, Perspectives of New Music, 28(1): 58-78. (Formalized Music: 268-288; Kéleütha: 75-87.)

(1991) Dynamic Stochastic Music, appeared in Formalized Music as Chapter 13.

(1991) More Thorough Stochastic Music. In (Alphonce B., and B. Pennycook, eds.), Proceedings of the International Computer Music Conference, McGill University, ICMC: 517-518. (Formalized Music, Chap. 14).

(1992) The New Upic System, appeared in Formalized Music: Appendix 3.

(1996). Determinacy and Indeterminacy, Organised Sound, 1(3): 143-155.

\section{Interviews}

Bourgeois, J. (1969). Entretiens avec Iannis Xenakis, Paris, Boosey and Hawkes.

Corlaix, O. and B. Gallet (1998). Entretien avec Iannis Xenakis, Musica Falsa, 2: 29.

Delalande, F. (1997) “Il faut être constamment un immigré”. Entretiens avec Xenakis, Paris, BuchetChastel/INA-GRM.

Feldman, M. and Xenakis, I. (1988). A conversation on music, Res 15: 177-181.

Harley, M. (1994). Musique, espace et spatialisation, Circuits vol. 5(2): 9-20.

Lyon, R. (1974). Propos impromptu, Courrier Musical de France vol.48: 130-133.

Pauli, H. (1975). Iannis Xenakis im Gespräch, Schweizerische Musikzeitung 115: 300-308.

Rey, A. (1984). Expliquez-vous Xenakis, Le Monde de la Musique, 71: 34-40.

Varga, B.A. (1996). Conversations with Iannis Xenakis, London, Faber and Faber.

Walter, E. (1968). Xenakis et la naissance d'un langage, Harmonie, 33: 18-26. 